\title{
Evolution of a Holocene delta driven by episodic sediment delivery and coseismic deformation, Puget Sound, Washington, USA
}

\author{
WALTER A. BARNHARDT * and BRIAN L. SHERROD $\dagger$ \\ *U.S. Geological Survey, 384 Woods Hole Rd, Woods Hole, MA 02543, USA (E-mail: \\ wbarnhardt@usgs.gov) \\ $\dagger$ †.S. Geological Survey, Box 351310, University of Washington, Seattle, WA 98195, USA
}

\begin{abstract}
Episodic, large-volume pulses of volcaniclastic sediment and coseismic subsidence of the coast have influenced the development of a late Holocene delta at southern Puget Sound. Multibeam bathymetry, ground-penetrating radar (GPR) and vibracores were used to investigate the morphologic and stratigraphic evolution of the Nisqually River delta. Two fluvial-deltaic facies are recognized on the basis of GPR data and sedimentary characteristics in cores, which suggest partial emplacement from sediment-rich floods that originated on Mount Rainier. Facies S consists of stacked, sheet-like deposits of andesitic sand up to $4 \mathrm{~m}$ thick that are continuous across the entire width of the delta. Flat-lying, highly reflective surfaces separate the sand sheets and comprise important facies boundaries. Beds of massive, pumice- and charcoalrich sand overlie one of the buried surfaces. Organic-rich material from that surface, beneath the massive sand, yielded a radiocarbon age that is timecorrelative with a series of known eruptive events that generated lahars in the upper Nisqually River valley. Facies CF consists of linear sandbodies or palaeochannels incised into facies $S$ on the lower delta plain. Radiocarbon ages of wood fragments in the sandy channel-fill deposits also correlate in time to lahar deposits in upstream areas. Intrusive, sand-filled dikes and sills indicate liquefaction caused by post-depositional ground shaking related to earthquakes. Continued progradation of the delta into Puget Sound is currently balanced by tidal-current reworking, which redistributes sediment into large fields of ebb- and flood-oriented bedforms.
\end{abstract}

Keywords Earthquake, ground-penetrating radar, Mount Rainier, multibeam bathymetry, Puget Sound delta.

\section{INTRODUCTION}

Deltas form on coasts where the volume of sediment that is discharged by rivers exceeds the volume removed by waves and currents. Primary controls on the morphologic and stratigraphic evolution of deltas include changes in relative sea level (RSL) and the geometry of the receiving basin, which are both closely related to the tectonic setting of the coast. Large deltas generally do not form on leading-edge coasts because rivers tend to be small, and narrow continental shelves provide little space for sediment to accumulate (Inman \& Nordstrom, 1971; Wright \& Coleman, 1974). However, relatively small deltas can develop in fetch-limited estuaries such as fjords or narrow rift basins, because erosion by coastal processes is minimal (Williams \& Roberts, 1989; Colman et al., 2003). Unlike deltas on wide, tectonically stable margins, where cyclic patterns of distributary avulsion drive constructive/ destructive phases (Penland et al., 1988), deltas in geomorphically confined settings do not experience wide lateral shifts in distributaries. Delta 
evolution on tectonically active margins is primarily influenced by abrupt RSL changes (coseismic uplift and subsidence) and temporally dynamic rates of sediment supply (related to volcanic eruptions, debrisflows).

Changes in RSL determine the amount of accommodation or the space available for sediments to accumulate in the receiving basin. Jervey (1988, p. 47) explained that '...in order for sediments to be preserved, there must be space available below base level (the level above which erosion will occur)'. When RSL falls, accommodation decreases. If no space is available, sediment is bypassed to a more distal location where space exists, causing a regression or seaward shift in the position of the delta front. When RSL rises, accommodation increases. If sediment supply is insufficient to keep pace with the newly created accommodation space, the delta front experiences a transgression or landward retreat.

Rivers draining active volcanoes episodically receive large pulses of volcaniclastic sediment that are mobilized by eruptions, landslides or heavy precipitation on loose volcanic deposits (Kuenzi et al., 1978; Vessell \& Davies, 1981). These convulsive events commonly generate fastmoving, sediment-rich debrisflows or 'lahars', which descend from high elevations and can travel long distances. The ultimate runout distance depends on the volume and grain-size composition of the flow, and the geometry of the valley in which it travels (Smith \& Lowe, 1991). Debrisflow deposits in distal locations, far from the original source areas, commonly overlie dateable materials at lower elevations that can help elucidate the recurrence frequency of large flows (Scott et al., 1995).

This paper examines evidence of earthquakes and extreme sedimentation events in the late Holocene as recorded by the Nisqually River delta in western Washington. The Nisqually River originates on the slopes of Mount Rainier, a large and active stratovolcano of the Cascade Range, and flows into the southern Puget Sound (Fig. 1). Infrequent but large lahars have impacted the upper and middle reaches of the river numerous times, but the chronology of these events remains unclear because of a scarcity of reliable dates (Crandell, 1971; Scott et al., 1995). Geomorphic changes associated with earthquakes and sediment-rich floods have considerable potential to disrupt housing, transportation, and agriculture in the region. Strong earthquakes can also cause submarine landslides or slumps along the seaward margins of deltas, which redistribute large volumes of sediment into deeper water (e.g. Valdez, Alaska; Coulter \& Migliaccio, 1966). Similar hazards face the industrialized deltas of other rivers that drain Mount Rainier, such as the Puyallup River (Port of Tacoma) and the Duwamish River (Port of Seattle).

The objectives of this study are to determine the impact of coseismic subsidence and episodic large pulses of sediment on the stratigraphic and geomorphic evolution of the Nisqually River delta. Existing models of delta development are based on large deltas, such as the Mississippi River delta, which primarily occur on tectonically quiet coasts (Wright \& Coleman, 1974; Penland et al., 1988). These models do not account for the effects of earthquakes, extreme changes in sediment supply due to volcanic processes, or river discharge into narrow waterways with strong tidal currents. This paper envisages a conceptual model of delta evolution that is more analogous to the Samalá River in south-western Guatemala, which occurs on a convergent plate margin ringed by active volcanoes (Kuenzi et al., 1978). The Nisqually River experiences a similar, unusually dynamic range of sediment production and deposition. However, its delta has not undergone the same large-scale pattern of constructivedestructive behaviour related to highly variable sediment supply and erosion by open ocean processes. Instead, the Nisqually River delta has been largely sheltered from marine processes of erosion by inherited topographic features (i.e. glacial valleys) that exert a strong control on the location of major depocenters.

\section{SETTING}

The geology and large-scale topography of the Pacific Northwest are products of regional tectonics and Quaternary glaciations. Subduction of the Juan de Fuca Plate beneath North America fuels the active volcanoes of the Cascade Mountains. Pleistocene glaciations greatly modified the landscape, covering it with thick glacial deposits and sculpting deep, linear troughs that comprise present-day lakes and numerous arms of Puget Sound (Booth, 1994). The most recent advance of the Cordilleran Ice Sheet reached its maximum extent near Olympia ca 16,950 cal yr BP (Porter \& Swanson, 1998). The ice blocked northern Puget Sound and impounded large, proglacial lakes in the Puget Lowland, which subsequently drained during deglaciation as the ice retreated north (Thorson, 1980). 

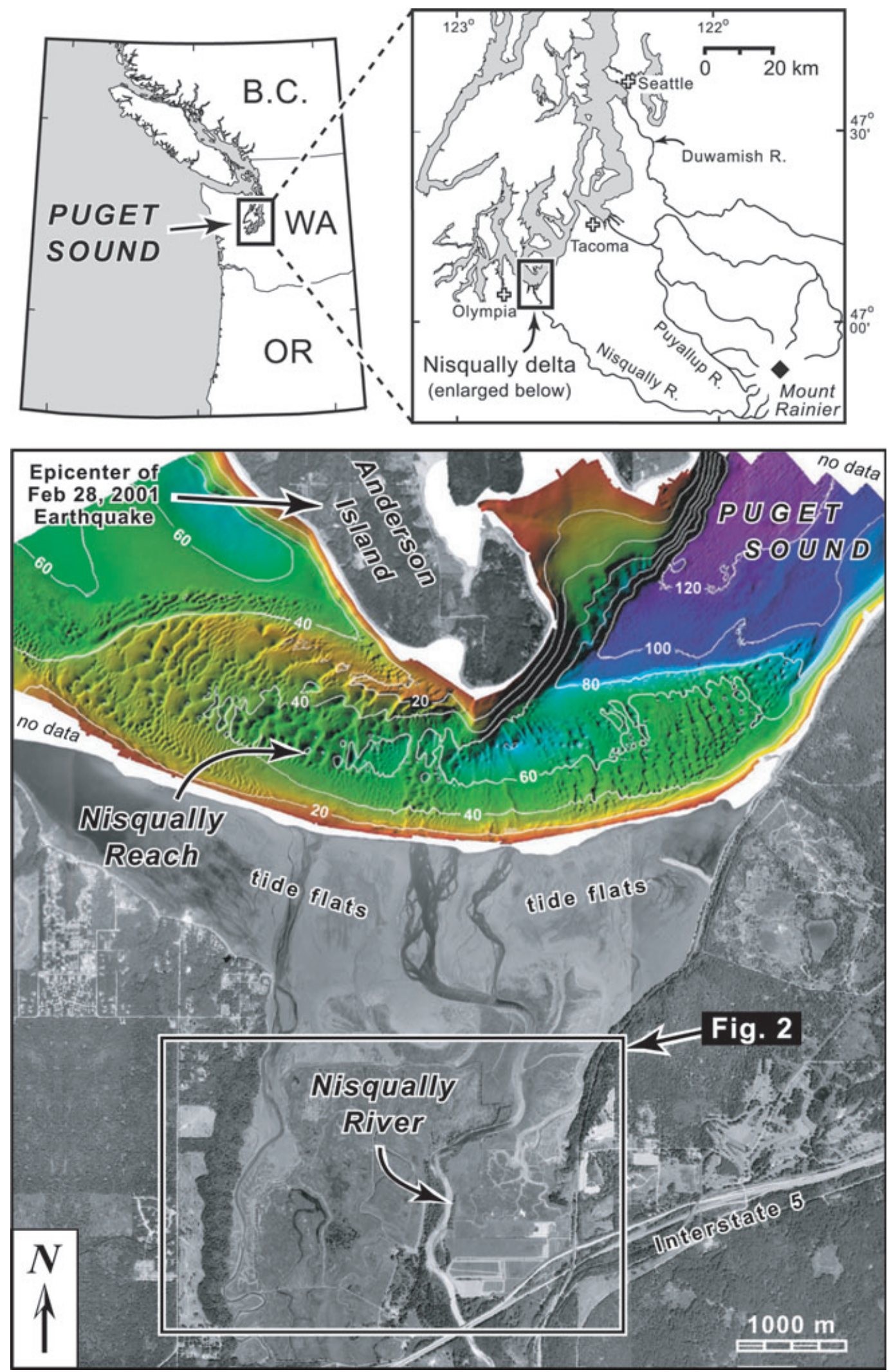

Fig. 1. Maps of Puget Sound region (top), depicting locations of the Nisqually River delta and major rivers that drain Mount Rainier. Vertical air photo of study area (bottom) with colour-coded, shaded-relief bathymetry of Nisqually Reach. Box indicates location of Fig. 2. Multibeam bathymetry is from Gardner et al. (2001). 
Relative sea level in the Puget Sound region has fluctuated in a complex pattern since the late Pleistocene, largely because of the time-transgressive nature of ice retreat and the effects of glacialisostatic rebound (Thorson, 1989; James et al., 2000). Regional sea-level curves show an initially high sea level that fell to a lowstand $c a 8000 \mathrm{yr}$ $\mathrm{BP}$, and then rose at different rates until the present (Clague et al., 1982). Holocene sea-level rise flooded the deep, glacially carved valleys of southern Puget Sound and transformed them into elongate marine embayments. Dragovich et al. (1994) estimated that sea level at $5700 \mathrm{cal}$ yr BP was approximately $8 \mathrm{~m}$ below the present datum, based on the position of middle Holocene deltas buried beneath younger alluvium.

The Nisqually River drains more than $800 \mathrm{~km}^{2}$ of the southern Cascade Mountains, including large areas of Mount Rainier (elevation $4366 \mathrm{~m}$ ) and adjacent foothills (Williams et al., 1985). The river flows generally west, descending steep gradients until it reaches the Puget Lowland, and then flows north to Puget Sound in a valley that was originally carved by Pleistocene glaciers. The down-channel distance from Mount Rainier to the site of delta construction is approximately $116 \mathrm{~km}$. The north-south oriented, elongate valley of the lower Nisqually River is $1-3 \mathrm{~km}$ wide and bounded on both sides by $30-100 \mathrm{~m}$ high walls of bedrock and glacial sediment, which confine the meandering channel as it approaches Puget Sound. Sedimentation is concentrated in this narrow zone, with alluvial and deltaic sediment filling the entire length of the former glacial valley. Distributary channels on the lower delta plain periodically shift position slightly as sediment accumulates at the river mouths. Two smaller streams, Red Salmon Creek and McAllister Creek, flow parallel to the main channel along the east and west margins of the valley, respectively (Fig. 2).

The Nisqually River discharges into Nisqually Reach, a main transverse arm of Puget Sound approximately $25 \mathrm{~km}$ southwest of Tacoma (Fig. 1). The constricted, U-shaped passage has a maximum tidal range of $5.09 \mathrm{~m}$ with current velocities of up to $0.95 \mathrm{~m} \mathrm{~s}^{-1}$ (Pentcheff, 2000). Older bathymetric charts of Nisqually Reach depict a submarine terrace at $\approx 60 \mathrm{~m}$ depth that exhibits a hummocky upper surface with numerous small, closed depressions (U.S. Navy, 1953). Bathymetric relief of up to $10 \mathrm{~m}$ occurs over horizontal distances of $100 \mathrm{~m}$ or less. A study by students at the University of Washington (1970) speculated that the terrace may represent an early
Holocene delta that formed at lower sea level, or the hummocky deposits of an ancient, delta-front landslide, possibly caused by an earthquake. Indeed, the Nisqually delta lies only a few kilometres from the epicentres of damaging earthquakes that struck in 1949 (M 7.1) and 2001 (M 6י8). Both earthquakes caused widespread liquefaction and other ground failures in the region (Chleborad \& Schuster, 1990; Walsh et al., 2002).

\section{METHODS}

Multibeam bathymetric data in Nisqually Reach were collected from the Rainier, a NOAA research vessel that carries four 9-m survey launches (Gardner et al., 2001). The Rainier has an Elac SeaBeam $1050 D^{1}$ system that was operated at $180 \mathrm{kHz}$; two survey launches have Elac SeaBeam $1180^{1}$ systems $(150 \mathrm{kHz})$; and two launches have Reson $8101^{1}$ systems $(240 \mathrm{kHz})$. Navigation was based on differential GPS and all depth measurements were corrected for tides and referenced to mean low water as the vertical datum. The point data were gridded at 3-m spatial resolution.

Approximately $12 \mathrm{~km}$ of ground-penetrating radar (GPR) profiles were collected on the delta, using a pulseEKKO $100^{1}$ system with a $1000-\mathrm{V}$ transmitter and antenna frequencies of 50 and $100 \mathrm{MHz}$ (Fig. 2). In principle, GPR transmits a short pulse of electromagnetic energy into the ground and then precisely measures the arrival time of reflected waves, similar to seismic reflection techniques (Davis \& Annan, 1989). Image quality was optimized in the field by stacking 32 shots at each point along a profile and by subsequent processing of the digital data. Common midpoint (CMP) surveys were performed to estimate the velocity of GPR signals and convert travel time to depth. A uniform velocity of $0.06 \mathrm{~m} \mathrm{~ns}^{-1}$ was applied to all profiles. No elevation corrections were made because topographic relief on the delta is very low.

Sixteen vibracores were collected in a transect across the delta (Fig. 2) to calibrate or 'ground truth' interpretations of GPR data and to collect samples for radiocarbon dating. The cores were $7 \cdot 6 \mathrm{~cm}$ in diameter and up to $5 \cdot 6 \mathrm{~m}$ long. Locations were determined with GPS. Cores were split, visually described, and photographed. Sediment

\footnotetext{
${ }^{1}$ Any use of trade names is for descriptive purposes only and does not necessarily indicate endorsement by the U.S. Geological Survey.
} 


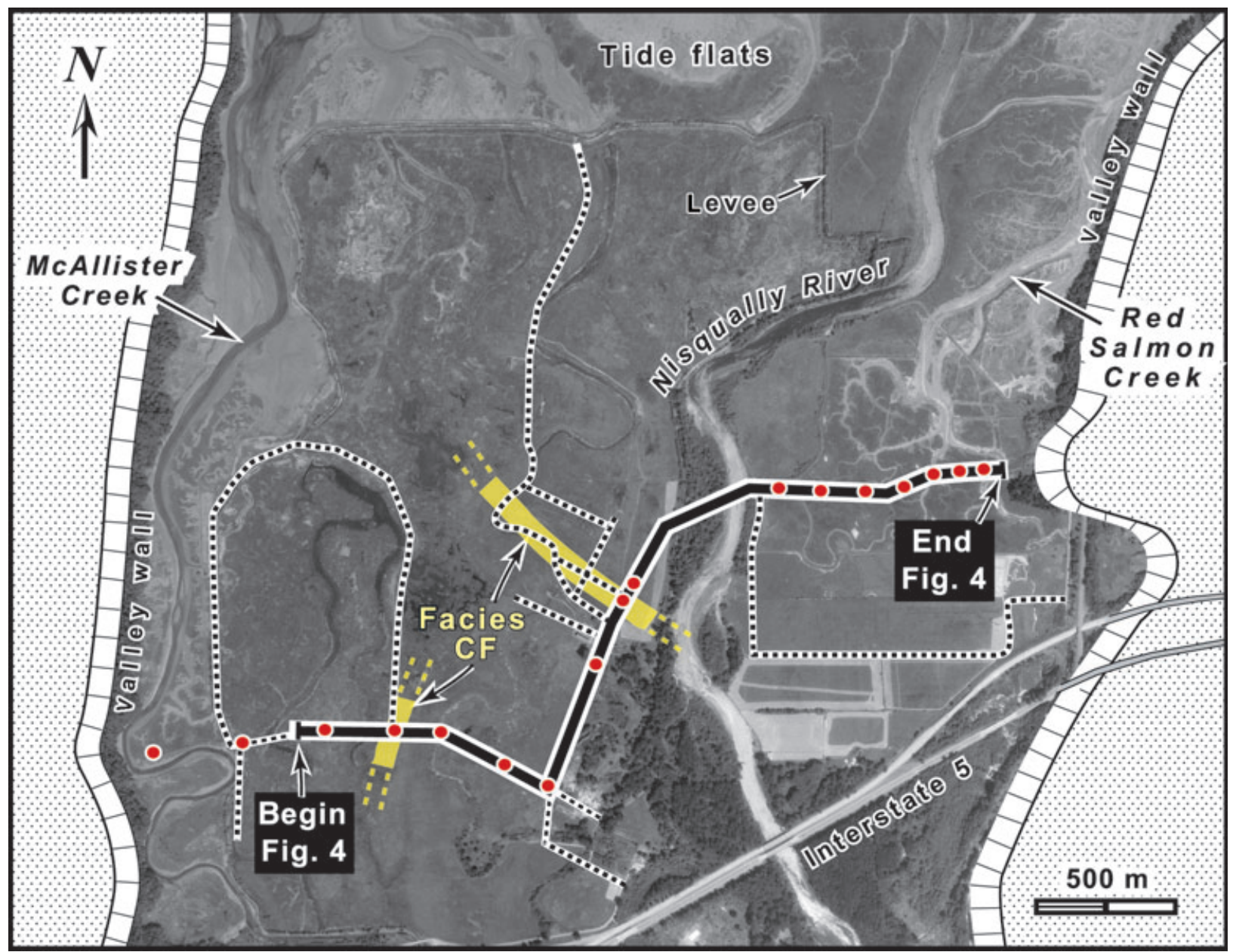

Fig. 2. Air photograph of Nisqually River delta showing GPR profiles (dashed lines) and vibracore sites (red dots). Solid black line represents location of stratigraphic section in Fig. 4. Channel-fill deposits of facies CF are shown in yellow. Stippled pattern indicates upland areas of Pleistocene sediment. See Fig. 1 for location.

Table 1. Description of radiocarbon-dated samples.

\begin{tabular}{|c|c|c|c|c|c|c|}
\hline Facies & Core no. & $\begin{array}{l}\text { Sample } \\
\text { description }\end{array}$ & $\begin{array}{l}\text { Age } \\
\left({ }^{14} \mathrm{C} \text { yr BP }\right)\end{array}$ & $\begin{array}{l}\text { Age* }^{*} \\
\text { (cal yr BP) }\end{array}$ & $\begin{array}{l}\text { Depth in } \\
\text { core }(\mathrm{m})\end{array}$ & Lab no. \\
\hline $\mathrm{CF}$ & NQ-1 & Wood fragment & $540 \pm 40$ & $570-520$ & $3 \cdot 10$ & Beta-143152 \\
\hline $\mathrm{CF}$ & NQ-3 & Wood fragment & $840 \pm 35$ & $790-670$ & $3 \cdot 43$ & WW-3678 \\
\hline S1 & RSC-4 & Twig, seeds & $1210 \pm 35$ & 1190-1060 & $1 \cdot 43$ & WW-3676 \\
\hline S1 & RSC-4 & Wood fragment & $1420 \pm 40$ & 1390-1280 & $3 \cdot 62$ & Beta-157963 \\
\hline S1 & RSC-4 & $\begin{array}{l}\text { Wood (outer rings, } \\
\text { bark intact) }\end{array}$ & $1520 \pm 35$ & 1420-1330 & $4 \cdot 07$ & WW-3677 \\
\hline S1 & RSC-5 & Wood fragment & $1790 \pm 40$ & $1720-1540$ & $3 \cdot 49$ & Beta-57964 \\
\hline $\begin{array}{l}\text { Surface R2 } \\
\text { (base of S1) }\end{array}$ & NQ-2 & Seeds & $2340 \pm 40$ & $2370-2320$ & $4 \cdot 54$ & Beta-157962 \\
\hline
\end{tabular}

*Calendar years at two sigma (95\% probability) calculated using the CALIB calibration method (Stuiver \& Reimer, 1993).

samples were analysed with standard sieves to determine texture (sand fraction only). Peels were made of selected cores using a flexible grouting method (Atwater et al., 2001) that revealed subtle bedding and sedimentary structures. Wood frag- ments were rinsed in tap water and oven-dried at $80{ }^{\circ} \mathrm{C}$ prior to submission for radiocarbon dating. All radiocarbon dates (Table 1) are reported in uncalibrated ${ }^{14} \mathrm{C}$ yr $\mathrm{BP}$ to conform with dates published by Scott et al. (1995). Dates were also 

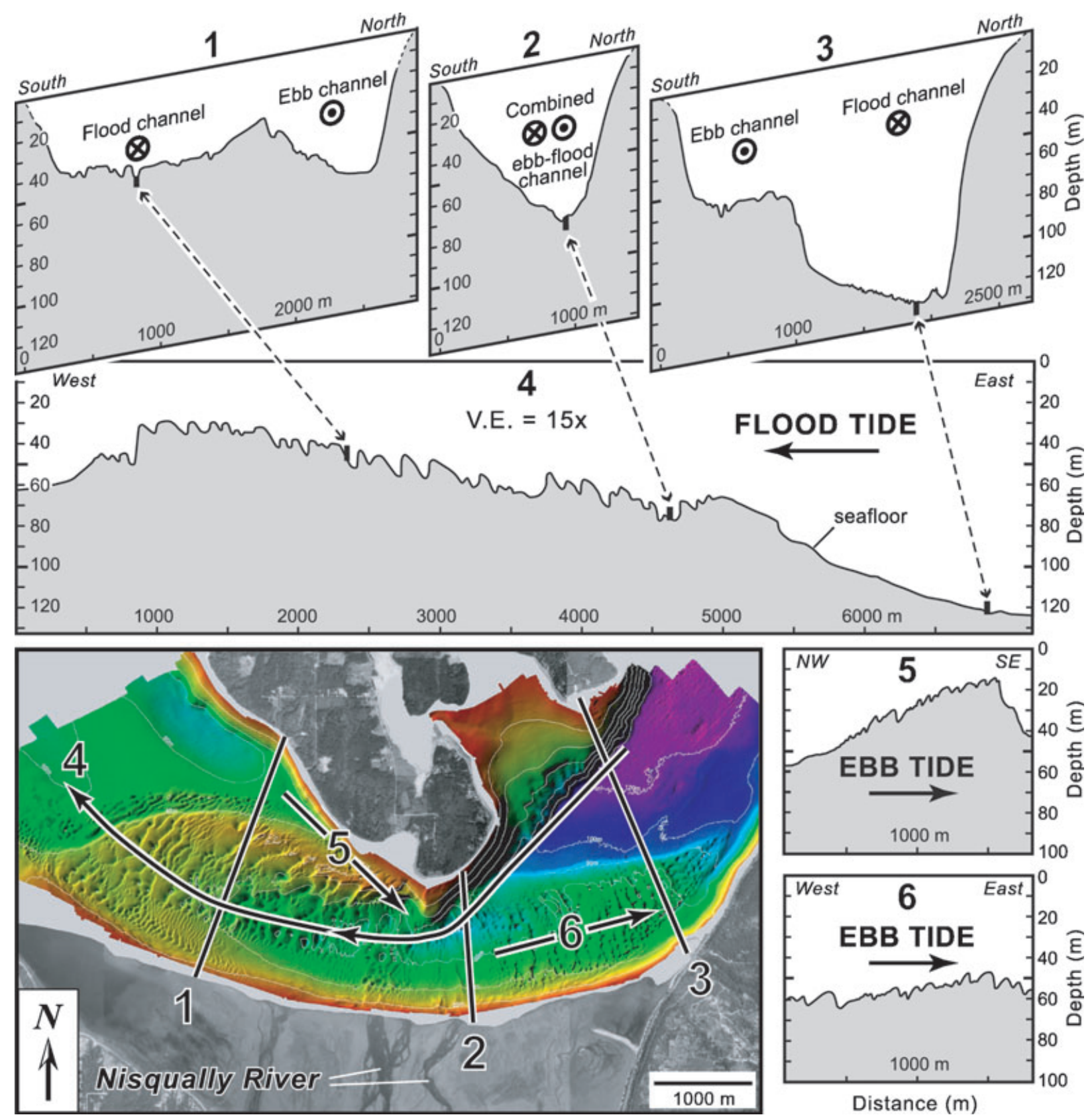

Fig. 3. Bathymetric profiles derived from multibeam data in Nisqually Reach. The curved passage progressively shoals from east to west, and has a narrow constriction at the mouth of the Nisqually River (profiles 1, 2 and 3). Asymmetric dunes indicate a dominance of flood-tidal currents in the main thalweg (profile 4). Fields of smaller bedforms exhibit a reverse asymmetry, indicating a separate return path for weaker ebb-tidal currents (profiles 5 and 6). Flood and ebb flows apparently cross in the centre of the passage. Vertical and horizontal scales are the same in all profiles.

calibrated using the CALIB conversion method of Stuiver \& Reimer (1993).

\section{DELTA-FRONT MORPHOLOGY}

High-resolution bathymetric data from Nisqually Reach (Fig. 3) indicate that tidal processes exert an important control on delta-front morphology. Strong tidal currents make a nearly $90^{\circ}$ turn through the U-shaped passage and scour the arcuate front of the delta, which is located on the outer or 'cut bank' side of the curve. An extensive tidal flat is exposed at low tide, and the submerged delta front slopes seaward at angles of $10^{\circ}$ to more than $20^{\circ}$. Water depths 
reach up to $80 \mathrm{~m}$ in the narrow, central passage. Two large deposits of sandy sediment, one on either side of the river mouth, comprise the submarine terrace at $40-60 \mathrm{~m}$ depth that was originally mapped with single-beam sonar (U.S. Navy, 1953). Multibeam sonar shows that the paired deposits are lobate in plan view. One lobe occurs on either side of the narrow central passage and they are unequal in size. The relatively smaller deposit extends to the east (ebb-oriented) and the larger deposit extends to the west (flood-oriented).

The western lobe is a large tidal sandbody with a length of about $4000 \mathrm{~m}$. It is asymmetric in profile along its axis, gradually shoaling from east to west in a flood-tidal direction (Fig. 3, profile no. 4). The crest lies in depths of less than $30 \mathrm{~m}$, and then abruptly steepens and drops down into water depths of about $60 \mathrm{~m}$. The sloping surface of the western lobe is covered by a field of sandy bedforms with wavelengths ranging from $1 \mathrm{~m}$ to over $200 \mathrm{~m}$, and amplitudes of up to $12 \mathrm{~m}$. These smaller bedforms are also asymmetric in crosssection, with steep avalanche faces oriented in a flood-tidal direction.

The eastern lobe is relatively small with a length of about $3000 \mathrm{~m}$, and is also asymmetric in profile. The sloping ramp gradually shoals from west to east in the direction of ebb-tidal flow, and reaches a minimum depth of about $50 \mathrm{~m}$. The downstream edge abruptly steepens and drops down into water depths of about $100 \mathrm{~m}$. The ramp is covered with sandy bedforms up to $100 \mathrm{~m}$ long and 3-4 m high, which are also asymmetric and oriented with steeper lee sides facing east in an ebb-tidal direction (Fig. 3, profile no. 6).

\section{DELTA-PLAIN STRATIGRAPHY}

Stratigraphic studies focused on a transect across the delta from Red Salmon Creek on the eastern margin, across the Nisqually River, to McAllister Creek on the west (Fig. 2). Two recurring types of sediment deposit were recognized on the basis of reflection characteristics in GPR profiles: (i) a sheet-like or tabular facies S, and (ii) a channelfill facies CF. The delta stratigraphy comprises stacked channel and sheet units, separated by key surfaces. Each unit exhibits a distinctive geometry, spatial extent, stratigraphic setting and internal structure (Huggenberger, 1993; van Heteren et al., 1996; van Overmeeren, 1998). The surfaces between the units have been mapped and used to subdivide the stratigraphy. The approach is comparable to the seismic-stratigraphic techniques of Mitchum et al. (1977), which emphasize the importance of unconformities that separate sedimentary units.

In general, the delta architecture exhibits a basic 'layer-cake' stratigraphy. Flat-lying sheets of mostly sandy material (facies S) are locally incised by channel-fill deposits (facies CF), all capped by a thin layer of organic-rich surficial sediment (Fig. 4). The lithostratigraphy and biostratigraphy of the surficial unit are described in detail by Sherrod (2001), and are not examined in this study. Facies boundaries are marked by laterally continuous reflections that indicate strong contrasts in electromagnetic properties. Three of these prominent reflections (R1, R2 and R3) are mapped with GPR beneath large areas of the delta, where they separate stacked deposits of facies S. Seventeen cores and two cutbank exposures along tidal creeks were examined to verify interpreted GPR sections. Only the deepest facies, S3, and surface R3 were not sampled. The depositional units presented here are defined by both geophysical and lithological properties.

\section{Description of facies}

\section{Facies $S$}

These tabular or sheet-like deposits are the most common facies comprising the delta. Three units of this facies were observed in GPR records and are designated, from top to bottom, S1 through S3 (Fig. 5). They are stacked in an orderly, layer-cake fashion and extend laterally across the entire delta, except beneath the modern river channel where data are lacking. Individually, the deposits range in thickness from 1 to $4 \mathrm{~m}$ and, cumulatively, they comprise the bulk of the near-surface deltaic sequence. The units are internally massive to stratified on GPR profiles. Zones that are massive (i.e. lacking internal reflections) interfinger or grade laterally into zones that are highly stratified. Seaward-dipping clinoforms were locally observed in unit S2 (Fig. 6), and were limited to the central part of the delta.

Strongly reflective boundaries (surfaces R1, R2 and R3) mark the top of the individual units (facies S1, S2 and S3, respectively). Relief on these smooth, flat-lying surfaces is low. Surfaces R1 and R2 are traceable, nearly continuously, over horizontal distances of more than $2 \mathrm{~km}$. Their large lateral extent and continuous nature provide key stratigraphic markers. Surface R1 overlies the uppermost deposit of facies $S$ and is the shallowest of the three bounding surfaces; it 


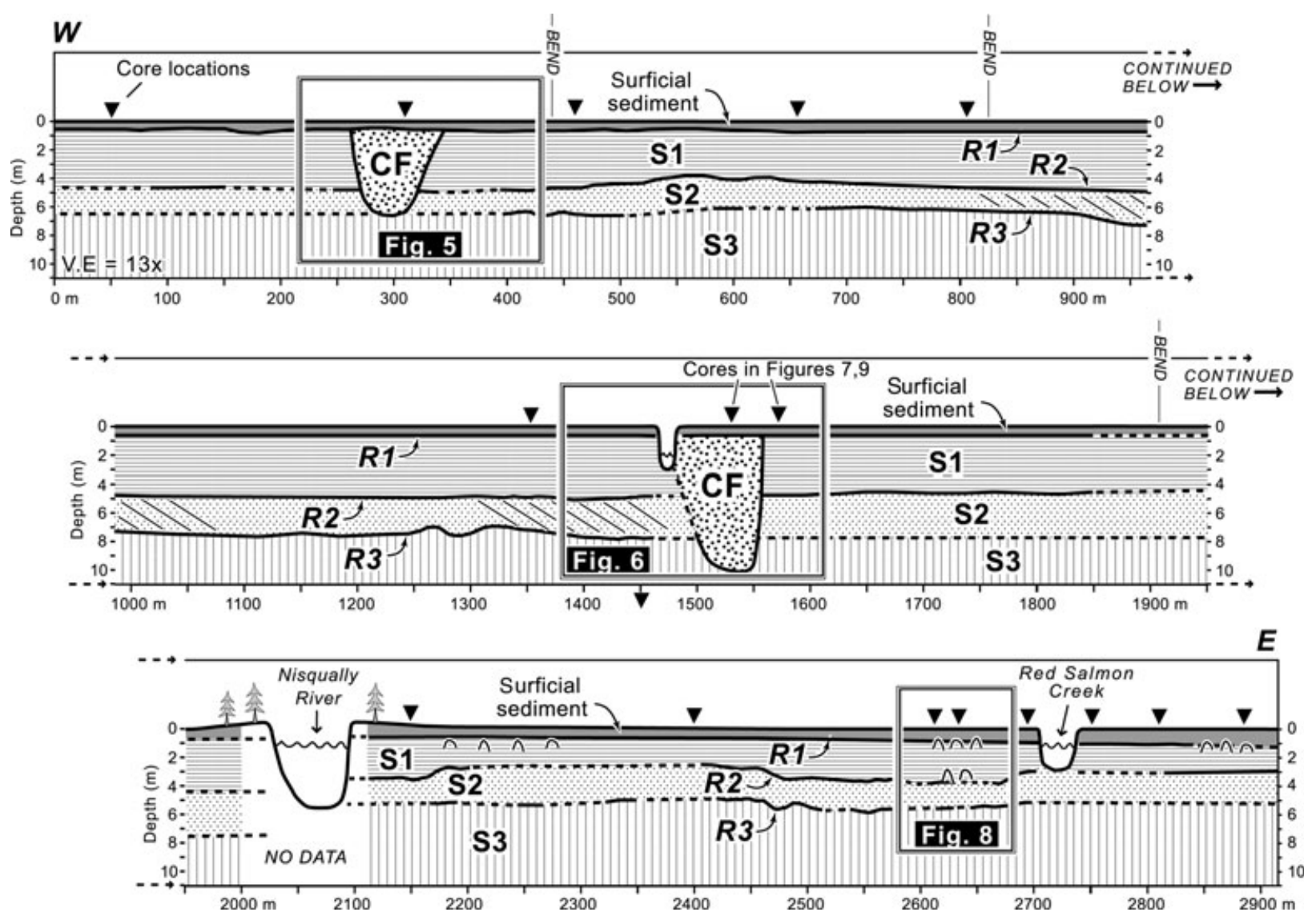

Fig. 4. Interpreted stratigraphic section across the Nisqually River delta, shown in three panels from west (upper left) to east (lower right). Black triangles indicate locations of cores. Vertical exaggeration is $13 \times$. See Fig. 2 for location.

lies less than $1 \mathrm{~m}$ beneath the ground everywhere in the study area. Surface R2 occurs about $3 \mathrm{~m}$ below the delta surface near the valley walls and gently descends to about $5 \mathrm{~m}$ deep in the centre of the delta. Surface R3, the deepest of these reflections, lies about $5 \mathrm{~m}$ below the ground near the valley walls, and dips down to depths of about $8 \mathrm{~m}$ in the centre of the delta. Unlike R1 and R2, this deeply buried R3 surface is discontinuous and only locally observed, probably due to limitations of the GPR system or the presence of conductive pore fluids or clay deposits.

Facies S primarily consists of planar- and crossbedded, fine to medium sand with minor gravel, locally interbedded with layers of massive sand and layers of finely laminated silt (Fig. 7). The stratified sandy deposits have mean grain sizes of $3 \cdot 0-1 \cdot 25$ phi and are moderately well sorted $(0 \cdot 5-$ $0 \cdot 7$ phi). Sediment colours range from dark grey (N 3/1) to reddish brown (5YR 3/2) on the Munsell colour scale. The texturally immature, angular grains of sand are volcanic in origin, based on their andesitic composition and the presence of scoria, pumice and volcanic glass. Minor amounts of scoria and pumice reach granule size (2-3 $\mathrm{mm}$ diameter). Light-coloured pumice grains are more abundant in the massive sandy deposits than the stratified deposits. Pieces of charcoal and wood are common. Sandy strata in several cores are deformed and exhibit evidence of sediment mobilization and flow, such as folding, minor faulting, and sand-filled dikes and sills that intrude and crosscut silty layers. Undeformed strata immediately above and below these deformed zones indicate that the deformation was not caused by coring. The silty layers are $1-5 \mathrm{~cm}$ thick, contain minor fine sand, and are light grey in colour (N 7/1). Organic-rich material is finely disseminated throughout facies S, and locally forms peaty layers up to $20 \mathrm{~cm}$ thick.

A prominent characteristic of facies $S$ deposits is the presence of massive (i.e. structureless), poorly sorted layers of fine-coarse sand with minor gravel (Fig. 7). These massive layers are 10-50 cm thick and only occur in the lower part of facies S1, at or slightly above the basal 

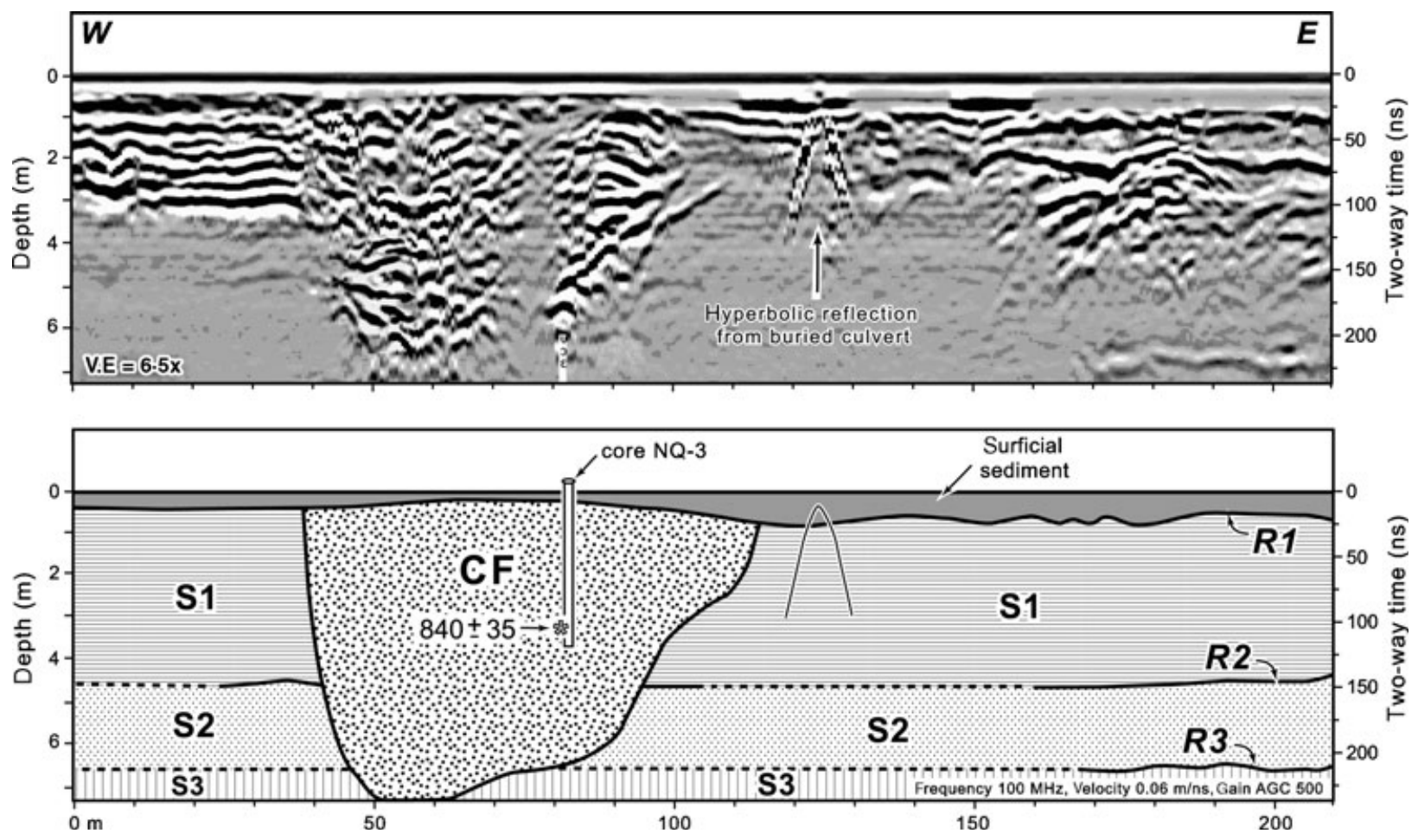

Fig. 5. GPR profile and interpreted section from the eastern part of the delta. See text for description of facies. Asterisk (*) indicates radiocarbon-dated sample from core; age is given in ${ }^{14} \mathrm{C}$ yr BP. Buried channel is about $8 \mathrm{~m}$ deep and $70 \mathrm{~m}$ wide. Location of profile indicated in Fig. 4.

contact. Larger grains of low density pumice and charcoal 1-3 $\mathrm{mm}$ in diameter are concentrated in the upper parts of these layers, which lack clayand silt-sized particles and exhibit a grainsupported fabric. The sand is loosely packed with numerous voids up to $5 \mathrm{~mm}$ in diameter, forming a distinctive spongy structure that is preserved in cores. Analogous deposits of 'bubblecavity sand' were described from bayhead deltas in British Columbia as '....associated with rapid deposition of sediment as linguoid ripples or megaripples. Air can be heard escaping from such bedforms as the tide rises (Syvitski \& Farrow, 1983, p. 233)'.

Although age data are lacking for the more deeply buried S2 and S3 units, the age of facies $\mathrm{S} 1$ is constrained by five AMS radiocarbon dates on organic samples collected in cores (Table 1). One core penetrated the contact that separates deposits of facies S1 and S2 (Fig. 6). This contact coincides with the highly reflective surface R2 and is associated with a 1-cm thick, organic-rich layer in the core (Fig. 7). Seeds from this surface, which marks the base of facies S1, give a maximum age for that facies of $2340 \pm 40{ }^{14} \mathrm{C}$ yr BP $(2370-2320 \mathrm{cal}$ yr BP). Four samples of wood were also collected from zones of hyperbolic reflections that were observed in GPR profiles adjacent to Red Salmon
Creek (Fig. 8). In this location, Sherrod (2001) previously described stumps of a drowned forest overlain by marsh peat. The wood fragments returned radiocarbon dates of $1420 \pm 40{ }^{14} \mathrm{C} \mathrm{yr}$ BP (1390-1280 cal yr BP), $1520 \pm 35{ }^{14} \mathrm{C}$ yr BP $\left(1420-1330 \mathrm{cal}\right.$ yr BP), and $1790 \pm 40{ }^{14} \mathrm{C}$ yr BP (1720-1540 cal yr BP). A sample of twigs and seeds was collected from near the top of facies S1, also from a zone of hyperbolic reflections in GPR data, and returned a date of $1210 \pm 35{ }^{14} \mathrm{C}$ yr BP (1190-1060 cal yr BP).

\section{Facies $C F$}

These deposits are relatively uncommon and only found in two locations in the central part of the delta, near the axis of the valley (Fig. 2). Multiple GPR crossings delineate the larger, northern deposit as an elongate feature at least $800 \mathrm{~m}$ long. It strikes northwest-southeast and apparently intersects the modern river channel. Data from the smaller, southern deposit are limited to a single GPR crossing, so the extent and orientation of the feature is uncertain. Geomorphic evidence on the delta surface suggests that it, too, is an elongate feature that strikes generally north-south.

The deposits of facies CF are 8-10 m thick and approximately $80 \mathrm{~m}$ wide. The base is bounded by an asymmetric, concave-up erosion surface 

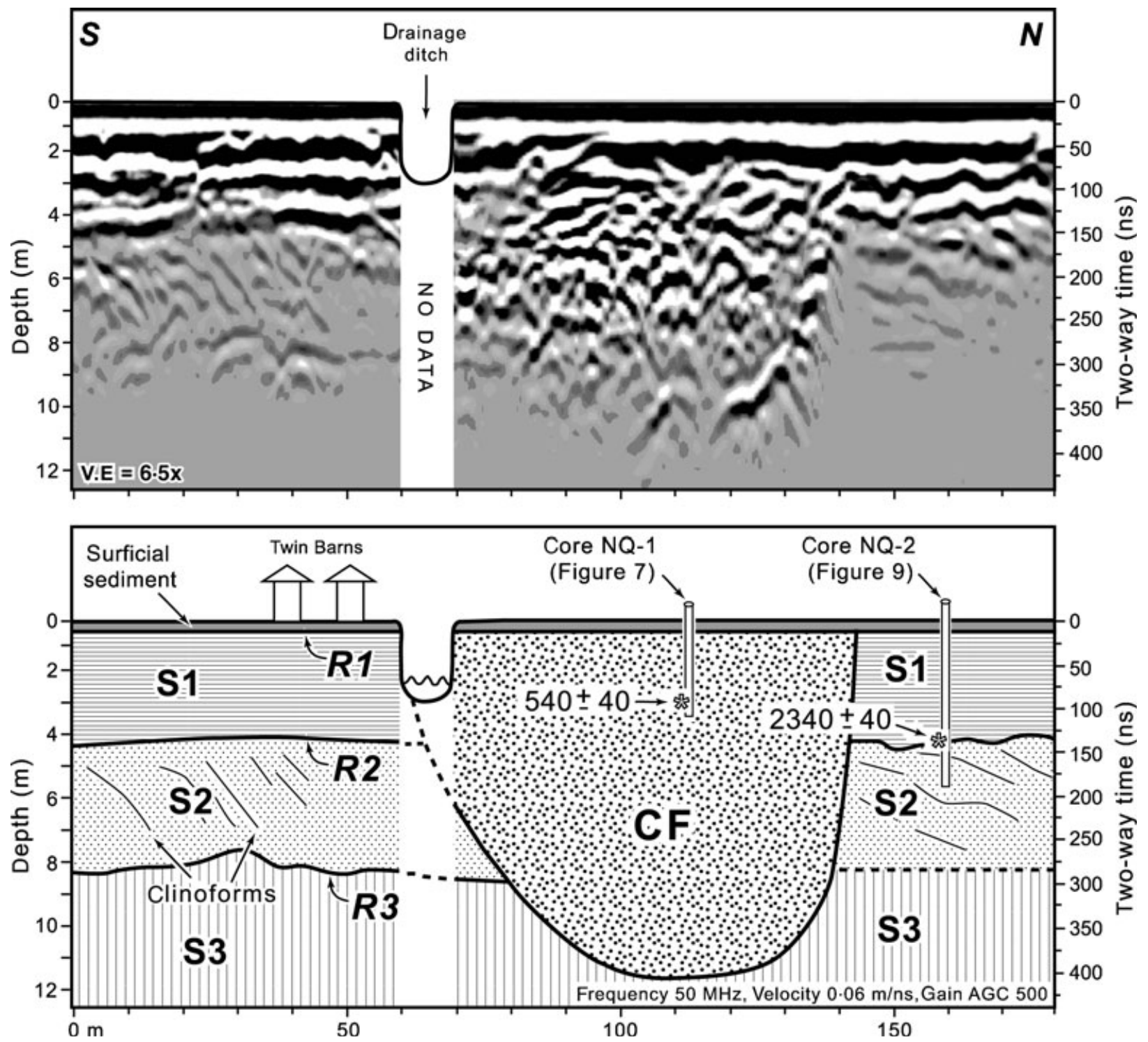

Fig. 6. GPR profile and interpreted section in central part of the delta. See text for description of facies. Asterisks $\left({ }^{*}\right)$ indicate radiocarbon-dated samples from cores; ages are given in ${ }^{14} \mathrm{C}$ yr BP. Buried channel is about $11 \mathrm{~m}$ deep and $80 \mathrm{~m}$ wide. Location of profile indicated in Fig. 4.

that is cut into facies $S$ units (Figs 5 and 6). No individual reflection marks the base or margins of the facies CF, rather it is defined by truncation of surfaces R2 and R3 and horizontal strata in older units. The top of facies CF is capped by the flatlying, GPR-reflective surface R1, which is buried approximately $50 \mathrm{~cm}$ below the ground. Internal reflections are generally incoherent and discontinuous, with extreme lateral variations in geometry and intensity. Small hyperbolic reflections were observed throughout these deposits.

Facies CF was sampled in three cores that penetrated to depths of 2-4 $\mathrm{m}$ below the delta surface; the lower part of facies CF was not sampled. Each core sampled the same three-part stratigraphy (Fig. 9) and terminated in moderately well sorted, fine sand that is up to $150 \mathrm{~cm}$ thick. The lower sandy unit is dark grey ( $\mathrm{N} 3 / 1)$ on the Munsell colour scale and has an average mean grain size of 2.5 phi. It contains abundant fragments of charcoal, wood, pumice, and reddish grains of scoria. Large wood fragments were sampled near the base of each core, where they filled the entire $7 \cdot 65-\mathrm{cm}$ diameter core barrels. Two samples of wood yielded radiocarbon dates of $840 \pm 35{ }^{14} \mathrm{C}$ yr BP $(790-670 \mathrm{cal}$ yr BP) and $540 \pm 40{ }^{14} \mathrm{C}$ yr BP $(570-520$ cal yr BP; Table 1$)$.

Sediment in stratigraphically higher sections of the cores (i.e. above the lower sand unit) consists of complexly interbedded layers of silt and sand. 
Facies S

Upper section missing

Dark grey medium sand; mod. well sorted; thin beds $2-10 \mathrm{~cm}$ thick. Minor light gray silt in layers, $0.5-2 \mathrm{~cm}$ thick.

Dark grey fine sand interbedded with light grey silt. Well developed sandy/silty couplets, 1-4 $\mathrm{cm}$ thick. Abundant finegrained organics.

Light grey silt; finely laminated with thin partings of fine sand. Abundant, fine-grained organics.

Dark grey medium sand, mod. well sorted; thinly bedded. Minor cross bedding. Light gray silt in thin beds $1-3 \mathrm{~cm}$ thick.

Organic-rich "peat"; dark reddish brown (5YR 3/2). Silty laminae $<1 \mathrm{~cm}$ thick.

Dark grey fine-coarse sand; v. poorly sorted, massive. Large grains of charcoal and pumice; air-filled cavities.

Dark grey fine sand; mod. well sorted. Interbedded with minor light grey silt in layers $0.5-7 \mathrm{~cm}$ thick. Organic-rich layer with seeds at top, $1 \mathrm{~cm}$ thick. Small stringers (sills, dikes) of medium sand intrude and crosscut bedding; fine scale folding and faulting.

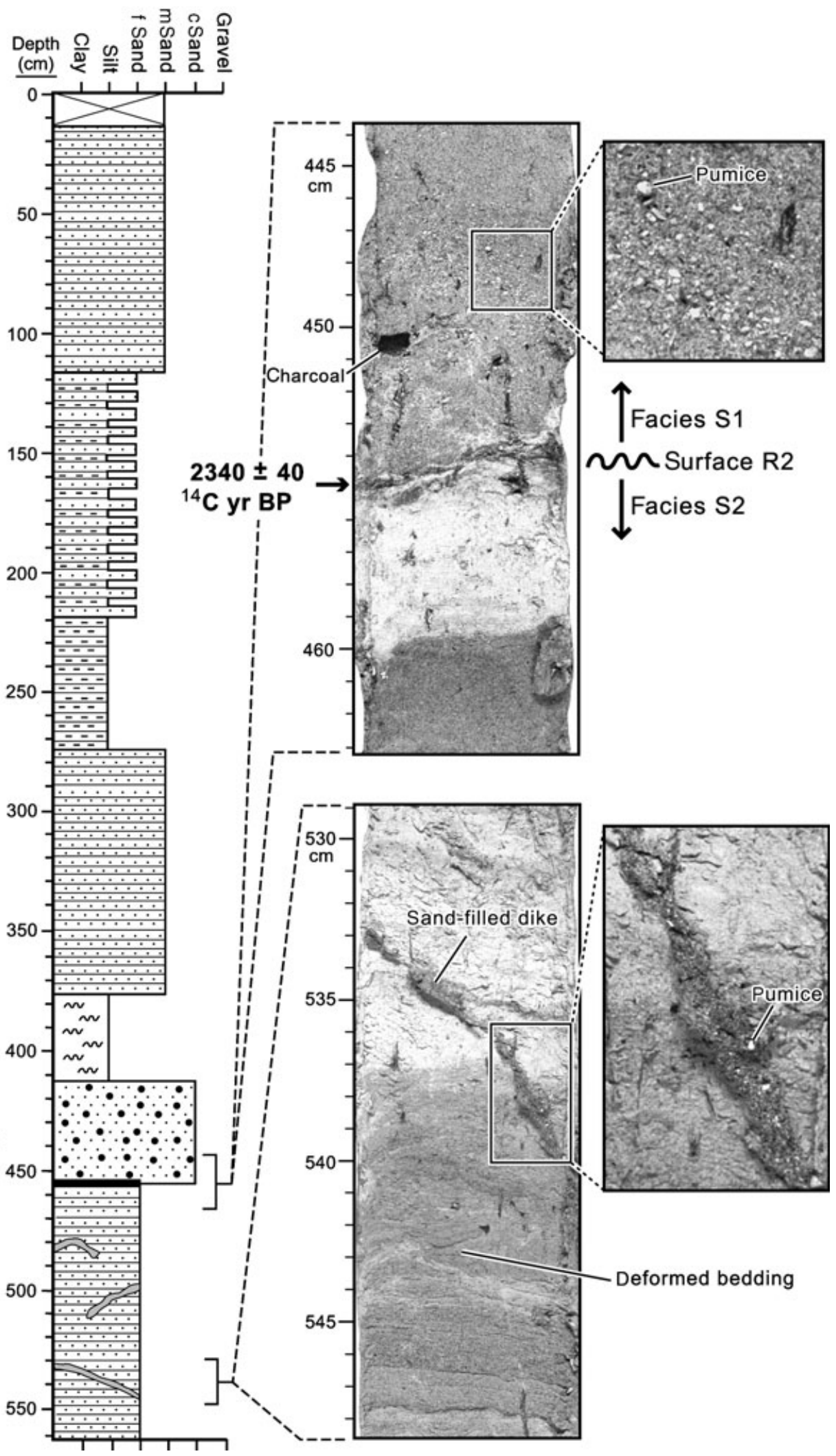

Fig. 7. Descriptive core log and photographs of peel from facies S. See Fig. 6 for GPR profile and location of core. 

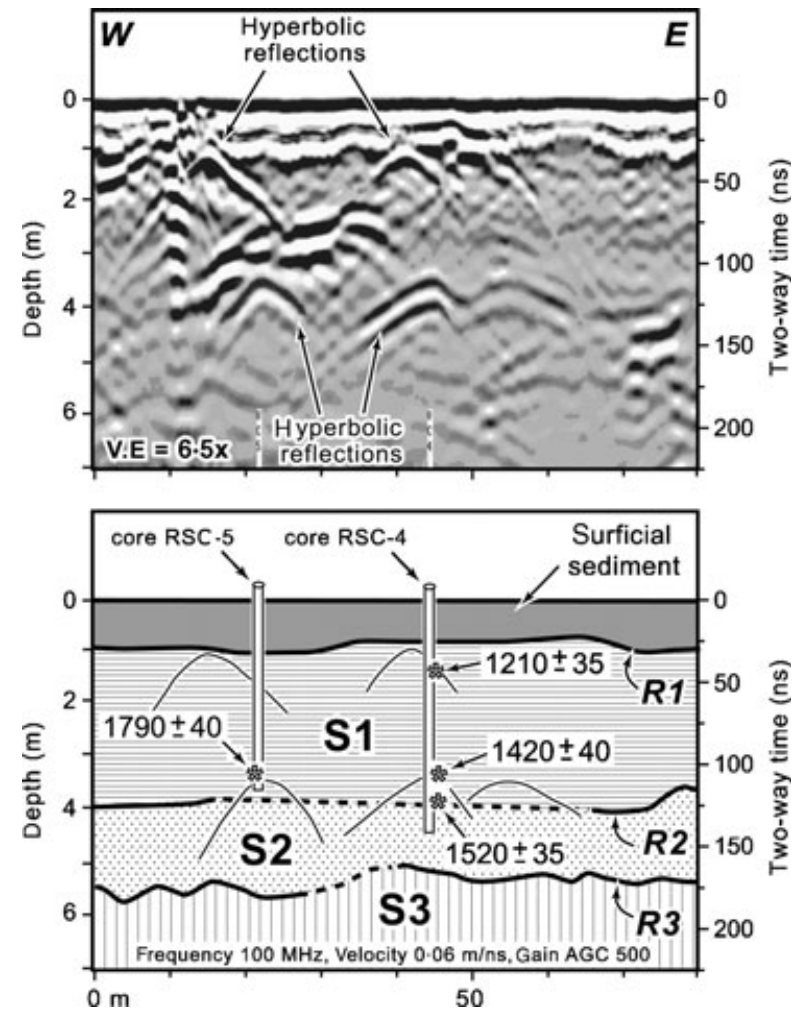

Fig. 8. GPR profile and interpreted section adjacent to Red Salmon Creek, in the eastern part of the delta. Asterisks $(*)$ indicate radiocarbon-dated samples from zones of hyperbolic reflections; ages are given in ${ }^{14} \mathrm{C}$ yr BP. See Fig. 4 for location of profile.

A variety of sedimentary structures is observed, including thin laminae, normal-graded beds, cross beds, and cut-and-fill structures (Fig. 9). These structures occur in multilayered units or bedsets (Campbell, 1967) that are 8-25 cm thick and exhibit an overall coarsening-upward sequence. The typical bedset has a sharp basal contact that is overlain by $1-2 \mathrm{~cm}$ of finely laminated silt and progressively coarsens upward into medium sand at the top. The silt beds are light grey (5Y 7/1) and have an average mean grain size of 4.5 phi. Sand in the upper part of the bedsets is dark grey (N 3/1) and has an average mean grain size of $2 \cdot 3$ phi. The coarser sand beds exhibit cross bedding and other tractionemplaced sedimentary structures. Each multilayered unit is, in turn, capped by a sharp contact. This stacked sequence is repeated several times and, in each core, reaches a cumulative thickness of $50-70 \mathrm{~cm}$.

In the upper $50-100 \mathrm{~cm}$ of facies CF, above the sequence of coarsening-upward sediment, deposits primarily consist of laminated, dark grey (N 3/ 1), fine to medium sand in beds $5-25 \mathrm{~cm}$ thick. These moderately sorted sandy beds are interbed- ded with thin beds, $2-5 \mathrm{~cm}$ thick, of finely laminated, silty very fine sand and very fine sandy silt. In contrast with underlying deposits, no large wood fragments, coarsening-upward sequences, or cross bedding were observed in the upper part of the cores.

\section{Origin of facies}

\section{Facies $S$}

The tabular, sheet-like deposits of facies S primarily consist of laminated silty and sandy layers, which are the product of normal streamflow or seasonal floods. The presence of cross bedding and scour-and-fill structures indicate that significant traction or bedload transport of sediment was the dominant process for most of the time represented by unit S1. These bedded deposits are underlain by a relatively thick layer of massive, poorly sorted sand (Fig. 7) that indicates different conditions existed when the lower part of unit S1 formed. The base of the massive sand deposit is at the same stratigraphic depth as surface R2 that was observed in GPR profiles (Fig. 6). The reflective nature of this contact apparently is generated by the contrast in sediment properties that occurs where massive sand at the base of unit S1 overlies laminated silt at the top of unit S2.

There are several possible origins of the massive sand layers. First, the original stratification might have been destroyed by liquefaction during earthquakes. Limited examples of such deformation were observed in several cores (Fig. 7). Second, bioturbation by organisms also might destroy stratification, but no fossil evidence of organisms was observed. The main argument against these two hypotheses is that stratified layers located above and below the massive strata are not visibly deformed, indicating that the lack of stratification is a primary feature. The third hypothesis is that the massive, more or less homogeneous layers are the result of rapid deposition from suspension, without subsequent reworking to create stratification (Boggs, 2001). Such rapid accumulation rates indicate deposition by sediment-rich flows, possibly the distal runout phases of debrisflows from Mount Rainier.

\section{Facies $C F$}

These deposits are interpreted as representing former channels of the Nisqually River or its distributaries that were incised into older deposits of facies S. The width and depth of the palaeo- 
Dark grey, fine-medium sand, moderately sorted. Interbedded with thin layers of light grey silt, 2$5 \mathrm{~cm}$ thick. Abundant rootlets and root casts.

Stacked, coarseningupward sequences; sharp upper/lower contacts. Light grey silt at base grades up into dark grey medium sand at top. Cross bedding and cutand-fill structures. Large wood fragments.

Dark grey fine sand, mod. well sorted. Thin, planar beds $1-5 \mathrm{~cm}$ thick. Abundant charcoal, pumice and scoria. Large wood fragments concentrated at base.

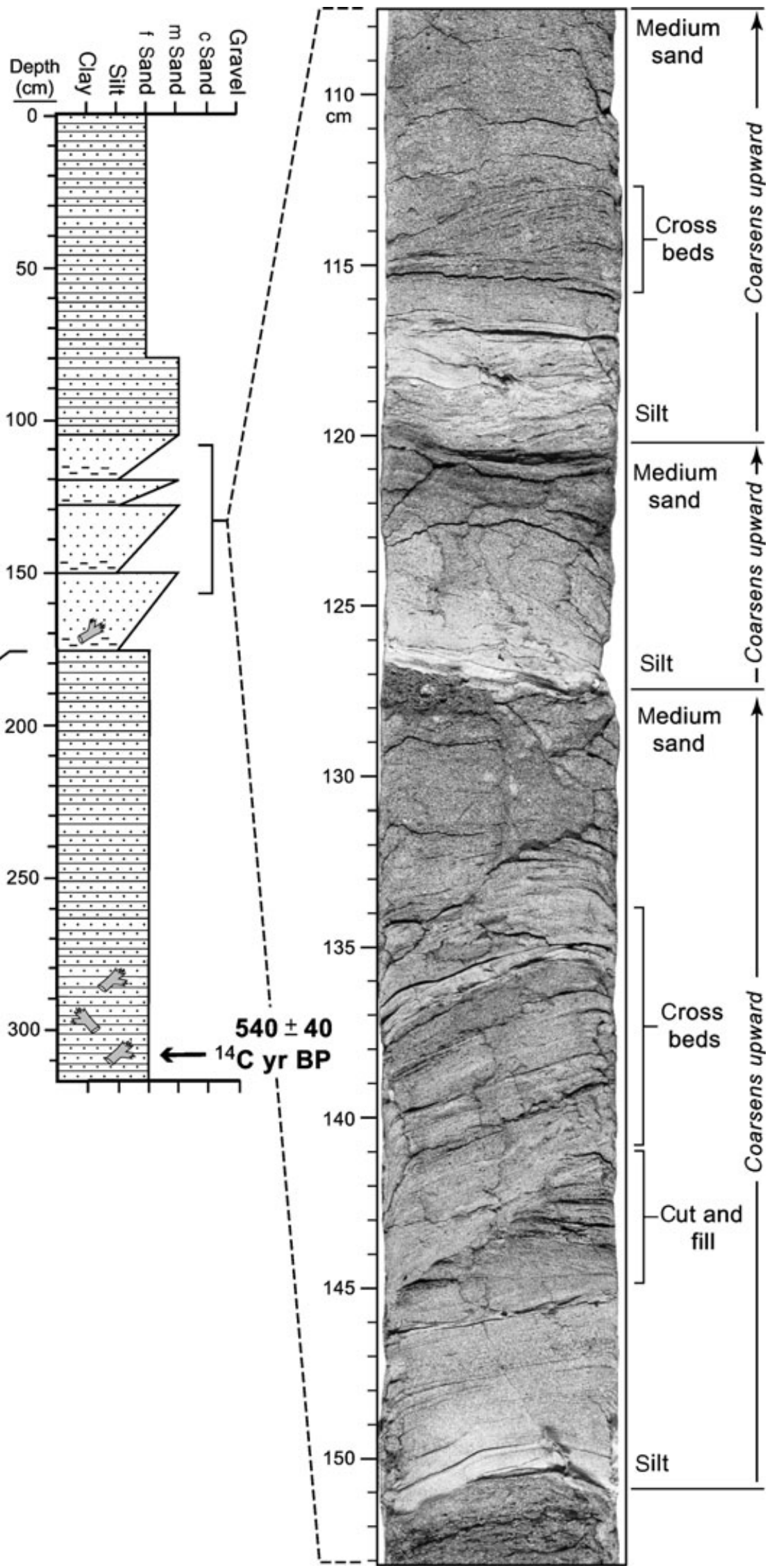

Fig. 9. Descriptive core log and photograph of peel from facies CF. See Fig. 6 for GPR profile and location of core. 
channels are similar to the dimensions of the modern river channel. Hyperbolic GPR reflections observed in facies CF probably represent buried logs, tree stumps, boulders or other point-source reflectors dispersed in a sandy matrix. Trees and other woody debris are commonly transported by large floods and might be the source of these reflections.

Coarsening-upward sequences are the distinguishing feature of facies CF deposits (Fig. 9), but their origin is uncertain. In general, the reverse size grading seen in parts of facies CF is attributed to rapid deposition from sediment-rich flows. The reverse-graded beds are thought to represent suspended load fluvial deposits that developed due to rapid deposition of muddy sediment from highly turbid water in conditions of low bed shear. On the Barwon River in Australia, for example, Taylor \& Woodyer (1978) observed that mud was deposited on the river banks during the rising limb of a flood, and was followed by deposition of sand during the peak flood. An alternative explanation is that facies CF does not represent fluvial deposits, in the strict sense, but instead was deposited in a tidally modulated, estuarine channel. The laminated silt at the base of each reverse-graded bed might represent minimal deposition during the incoming flood tide, and the sandy, upper parts are deposited later during ebb tide, when down-channel flows accelerate and sediment transport increases. These deposits are located several kilometres below the modern tidal limit of the Nisqually River. Both mechanisms that produce reverse-graded deposits require flows containing high concentrations of sediment. Other mechanisms include dispersive pressure, bed load transport lag and kinetic sieving, but these are unlikely due to the presence of cross-stratified sand in the coarsening-upwards sequences, which indicate traction-emplaced deposits.

\section{DEBRISFLOWS AND THEIR DISTAL EQUIVALENTS}

Large, sediment-rich floods in the Nisqually River valley typically begin on Mount Rainier as debrisflows and have occurred throughout the Holocene (Scott et al., 1995). Non-cohesive (granular or claypoor) debrisflows generally originate from heavy rain or syneruptive melting of snow and ice on steep volcanic slopes. Meltwater surges or outburst floods are generated and entrain surficial detritus into non-cohesive debrisflows that trans- form downvalley via dilution (Smith, 1986; Smith \& Lowe, 1991). As channel gradients decrease with distance from the volcano, normal streamflow processes take over the transport and deposition of abundant sediment. This genetic relationship, whereby highly viscous debrisflows are progressively diluted by stream water in more distal areas, has been observed at Mount St Helens, a volcano located about $80 \mathrm{~km}$ south-west of Mount Rainier (Scott, 1988). Rivers draining the volcano transported high sediment loads long after the original May, 1980 eruption, causing shoaling of important shipping lanes on the Columbia River (Meier et al., 1981). High rates of erosion also followed the 1902 eruption of Santa Maria Volcano in Guatemala, and drove progradation of the Samalá River delta about $7 \mathrm{~km}$ into the Pacific Ocean (Kuenzi et al., 1978). The period of rapid delta growth lasted about 20 years, and was followed by a destructive phase of delta retreat as sediment supply waned. These distal, stream-emplaced deposits are equivalent to the 'lahar-runout facies' of Pierson \& Scott (1985), a term avoided here because outcrop evidence is lacking to directly relate the spatially separated events. That is, the distal deposits on the Nisqually delta are not directly traceable upstream to the more proximal lahar deposits identified by Crandell (1971) and Scott et al. (1995). However, radiocarbon dating of wood in facies $\mathrm{S} 1$ and $\mathrm{CF}$ indicates that significant deposition on the delta occurred at approximately the same time as several lahar events upstream.

The maximum age of facies $\mathrm{S} 1\left(2340 \pm 40{ }^{14} \mathrm{C}\right.$ yr BP) falls within a period of intense lahar activity on Mount Rainier (Fig. 10). This period of activity lasted over 500 years and included the Round Pass, National and several nameless lahars (Scott et al., 1995). Volcaniclastic sand deposits, approximately the same age as in this study, also occur in the nearby Puyallup River valley and clearly originated as lahars (Pringle \& Palmer, 1992). The massive sand consists of angular grains having a volcanic provenance, based on andesitic mineralogy and the presence of scoria, pumice and lapilli. Small twigs from the lahar deposit yielded an uncorrected age of $2320 \pm 120$ ${ }^{14} \mathrm{C}$ yr BP (Palmer et al., 1991), which is time correlative with a block and ash flow deposit in the upper Puyallup valley, probably the National Lahar (Crandell, 1971). Wood underlying the National Lahar in the upper Nisqually valley constrains its maximum age to $2285 \pm 155{ }^{14} \mathrm{C}$ yr BP (Scott et al., 1995), which closely matches the maximum age of unit S1 in this study. Age-dating of wood fragments, which were collected from 


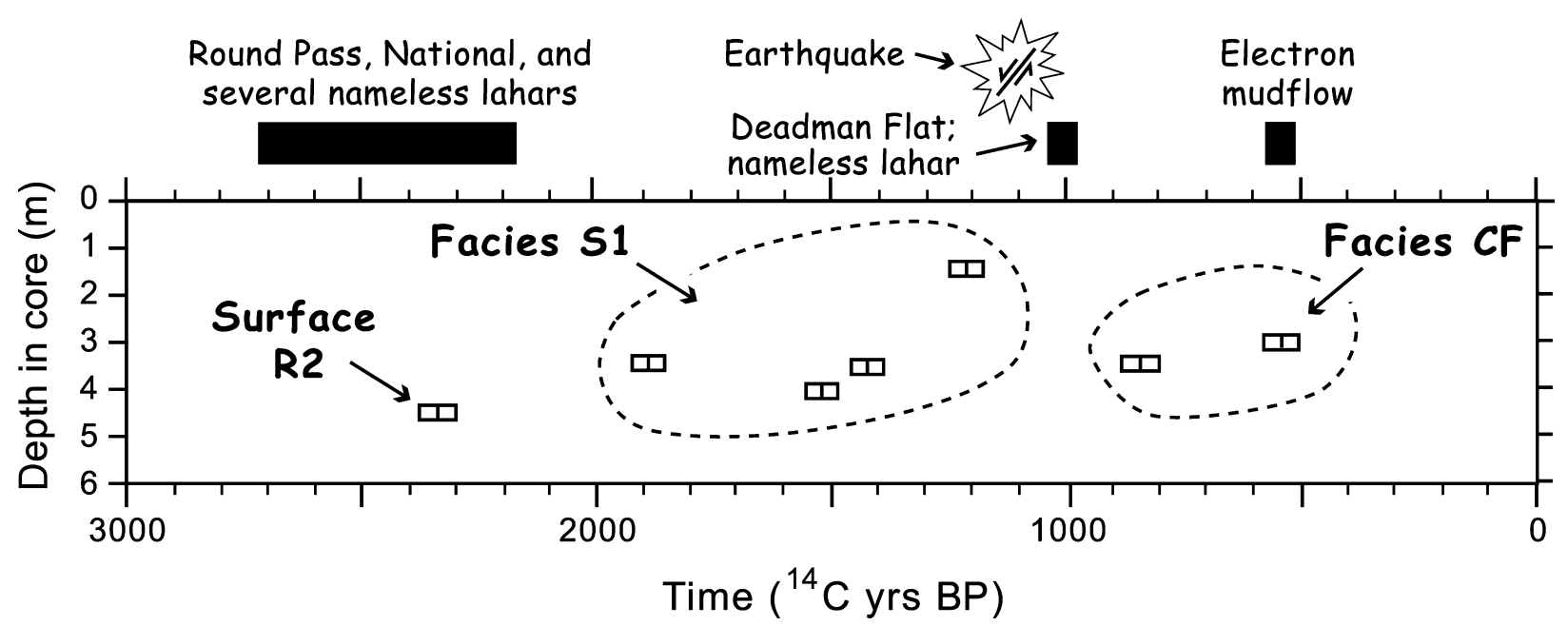

Fig. 10. Graph depicting radiocarbon ages of samples and their depth below the delta surface (open bars). Also shown are the approximate timing of large debrisflow events from Mount Rainier (black bars; Scott et al., 1995; Sisson et al., 2001) and a strong earthquake that struck the southern Puget Sound region (Sherrod, 2001).

different levels within unit S1, suggest that deposition continued until at least $1210 \pm 35$ ${ }^{14} \mathrm{C}$ yr BP. In the early stages of this time period, massive beds formed above surface R2, indicating relatively rapid sedimentation. In later stages, sedimentation slowed, and normal fluvial processes deposited stratified silt and sand.

Large wood fragments from the facies $\mathrm{CF}$ deposits indicate that the palaeochannels, shown in Figs 5 and 6, were active sometime before about $540{ }^{14} \mathrm{C}$ yr BP. The two available dates differ by about 300 radiocarbon years but roughly correlate with the timing of the Electron Mudflow (Fig. 10). The wood does not date the flows directly because older material may have been entrained and deposited, so the dates represent a maximum age on the depositional event(s) that filled the palaeochannels. These new dates, however, bracket the uncalibrated $585 \pm 125{ }^{14} \mathrm{C}$ yr BP age of a western red cedar approximately $10 \mathrm{~km}$ upstream of the study area (Scott et al., 1995). The cedar tree grew on a deposit correlated with the National Lahar, and was buried by deposits of the Electron Mudflow.

\section{EARTHQUAKES AND LIQUEFACTION}

Prehistoric earthquakes involving upper crustal faults have impacted the Puget Sound region in the late Holocene, including a major event on the Seattle fault about 1100 years ago (Atwater \& Moore, 1992). Coseismic subsidence of the Nisqually River delta during this event was recorded by estuarine and marsh sediment over- lying lowland soils (Sherrod, 2001). Low marsh peat buries in-situ stumps of Douglas fir that are exposed in outcrop on the east side of the delta at Red Salmon Creek. Radiocarbon dates on the buried stumps and Triglochin maritima rhizomes indicate submergence of 1-2 m (Sherrod, 2001). GPR profiles were run in areas adjacent to the outcropping forest soil and detected clusters of hyperbolic reflections that are interpreted as representing buried trees or stumps (Fig. 8). Core samples contained twigs and seeds at about the same age and depth as the buried forest described by Sherrod (2001), and returned a similar date of 1190-1060 cal yr BP. Wood sampled from deeper strata near the base of facies S1 returned dates of 1720-1280 cal yr BP, and might represent a forest buried by an earlier subsidence event. Based on the GPR data and cores alone, it is not possible to determine if the hyperbolic reflections represent in situ stumps that are rooted in place, rather than logs or boulders. Despite the uncertain source of these GPR anomalies, the earthquake clearly caused submergence of part of the delta top. The increased accommodation allowed surficial sediment to accumulate above unit surface R1, which truncates units $\mathrm{S} 1$ and $\mathrm{CF}$.

Liquefaction of sandy sediment on the delta was extensive during the February 2001 Nisqually earthquake, which was centred $52 \mathrm{~km}$ below Anderson Island (Fig. 1). Numerous sand boils, where a liquefied slurry of sand and water is vented out onto the surface, were concentrated in the vicinity of the channel-fill deposits of facies CF. The sandy deposits were particularly 
susceptible to liquefaction because of their relatively young age and loose consolidation. Hazard maps also assign high liquefaction potential to palaeochannel deposits in the Duwamish River valley near Seattle, which are the equivalent of facies CF in this study (Palmer et al., 1994). The sand-filled dike in facies S2 (Fig. 7) records at least one episode of earthquake-induced liquefaction, but the timing is not known. The core was collected before the February 2001 Nisqually earthquake, but the liquefaction event that created the sand-filled dike could have resulted from earthquakes that occurred nearby in 1949 and 1965. Those events generated extensive liquefaction and ground failure in the study area (Chleborad \& Schuster, 1990). Prehistoric earthquakes have caused liquefaction, too. Evidence of palaeoseismicity in the area includes sand blows and a sand-filled dike that cuts across a buried soil at McAllister Creek, indicating severe ground shaking at the time of subsidence about $1100 \mathrm{yr}$ ago (Sherrod, 2001).

\section{ANTECEDENT TOPOGRAPHY AND TIDAL REWORKING}

The antecedent topography of the Puget Lowland largely controls drainage pathways in the region. Three rivers drain Mount Rainier and empty into southern Puget Sound: the Nisqually, Puyallup and Duwamish Rivers (Fig. 1). All three rivers flow through glacial valleys with steep walls that concentrate fluvial sediment in a narrow zone. Dragovich et al. (1994) estimated that the Puyallup and Duwamish River deltas have grown seaward at average rates of 2.5 and $9.0 \mathrm{~m} \mathrm{yr}^{-1}$, respectively, since the middle Holocene. These two rivers presently discharge into the protected waters of small bays where the effects of waves and tides are minimal, thus fitting the description of river-dominated deltas (Wright \& Coleman, 1974). However, they lack the shallow, gently sloping receiving basin of the traditional 'birdsfoot' model, which was largely based on the Mississippi River delta. Progradation will probably decelerate as sediment fills the restricted embayments and the deltas protrude into deeper, more energetic waters of Puget Sound.

In contrast, the Nisqually River discharges directly into Puget Sound; its delta does not exist within a protective embayment. The Nisqually delta is considered a tide-dominated system during periods of normal river flow because strong tidal currents are largely responsible for sediment transport (Scott, 1982). The arcuate delta front lies at the northern terminus of the valley, forming a Y-shaped confluence where the northerly flow of the river meets the bi-directional, east-west flow of the tides (Fig. 3). Bathymetric profiles derived from historic charts show that the delta has advanced (prograded) and retreated (retrograded) in a complex pattern, with the delta-front shoreline migrating up to $35 \mathrm{~m}$ since the late 1800 s (Scott, 1982). The observed changes in the position of the delta front probably resulted from temporal variations in sediment supply and erosion by strong tidal currents. Slumps or slides are also likely to impact delta-front morphology, although bathymetric surveys show no evidence for submarine mass movements.

Nisqually Reach, the receiving basin for river discharge, exhibits some morphological components of a tidal inlet complex that are more commonly seen on barrier-island coasts (Hayes, 1979). For example, a pair of large sandbodies lie adjacent to the 'inlet', representing the terminal lobe and flood ramp of ebb- and flood-tidal deltas, respectively (Fig. 3). The lobe-shaped sandbodies extend east and west from the centre of Nisqually Reach, and are nearly mirror images of each other, with the western, flood-oriented lobe slightly larger. Both lobes are covered with smaller, asymmetric bedforms which indicate net sediment transport up the sloping ramps, away from the inlet, during different parts of the tidal cycle. Flood-oriented bedforms that occupy the main thalweg of Nisqually Reach are larger in wavelength and amplitude than ebb-oriented bedforms, which occupy a smaller ebb channel along the south-west margin of Anderson Island. The flow paths apparently cross in the centre of Nisqually Reach as the currents make the tight turn through the passage. The size and orientation of bedforms indicates a net, long-term transport of sediment westward in the direction of flood-tidal currents.

\section{CONCLUSIONS}

Active-margin processes largely control coastal evolution in the Puget Sound region, and differ significantly from processes that shape coastal environments in tectonically quiet settings. Earthquakes and volcano-derived sediment have had profound effects on the stratigraphic and morphologic development of the Nisqually River delta. Evidence of sediment liquefaction and flowage in cores records a past episode(s) of 
strong ground shaking generated by a prehistoric or recent earthquake(s). Earthquake-induced subsidence caused at least one episode of abrupt RSL rise, which provided new accommodation for the accumulation of thick fluvial-deltaic deposits. Interbedded non-marine sequences on the delta plain consist of massive, reverse and normal graded, cross-bedded and horizontally stratified deposits that indicate long periods of normal streamflow, punctuated by relatively short periods of rapid deposition by sedimentrich floods. These deposits probably represent the distal runout phases of debrisflows although the radiocarbon chronology obtained in this study only broadly correlates with specific events on Mount Rainier. The floods were not confined to upstream areas near the volcano, rather they delivered voluminous sediment to the lower river valley and delta over $100 \mathrm{~km}$ downstream of the mountain. The elongate geometry of the receiving basin focused sedimentation in a narrow corridor and, during times of high sediment supply, delta progradation was probably rapid. Linear deposits of sandy sediment suggest that channel avulsion occurred on the delta plain when the normal capacity of the river became insufficient to transport the volume of material supplied to it. Although the delta is located within a few kilometres of the February 2001 earthquake epicentre, bathymetric mapping found no recent evidence of submarine landslides along the narrow, steeply sloping delta front. Current rates of fluvial sediment supply are relatively low, and reworking by tidal currents is the major influence on delta-front morphology.

\section{ACKNOWLEDGEMENTS}

This study was supported by the Coastal and Marine Geology Program, and the Earthquake Hazards Program of the U.S. Geological Survey. We thank Robert Kayen, Eric Thompson, Ken Israel, and Phoebe Deyhim for help in the field. Don Bills and Wes Ward (USGS) made a generous loan of GPR equipment, and Steve Palmer (Washington Department of Natural Resources) built and helped us operate the vibracore system. Bill Hesselblatt and Nanette Seto (U.S. Fish and Wildlife Service) provided access to the Nisqually National Wildlife Reserve. Brian Atwater and Larry Phillips reviewed an early version of this paper and made many helpful suggestions. We also thank Kevin Scott, Peter Haughton, Gary
Smith and Vern Manville whose comments greatly improved the text.

\section{REFERENCES}

Atwater, B.F. and Moore, A.L. (1992) A tsunami about 1000 years ago in Puget Sound, Washington. Science, 258, 1614-1617.

Atwater, B.F., Baker, D., Barnhardt, W.A., Burrell, K.S., Haraguchi, T., Higman, B., Kayen, R.E., Minasian, D., Nakata, T., Satake, K., Shimokawa, K., Takada, K. and Cisternas, M. (2001) Grouted sediment slices show signs of earthquake shaking. EOS Trans. Am. Geophys. Union, 82, 603-608.

Boggs, S., Jr (2001) Principles of Sedimentology and Stratigraphy. Prentice-Hall, Upper Saddle River, NJ, 726 pp.

Booth, D.B. (1994) Glaciofluvial infilling and scour of the Puget Lowland, Washington, during ice-sheet glaciation. Geology, 22, 695-698.

Campbell, C.V. (1967) Lamina, laminaset, bed and bedset. Sedimentology, 8, 825-828.

Chleborad, A.F. and Schuster, R.L. (1990) Ground failure associated with the Puget Sound region earthquakes of April 13, 1949, and April 29, 1965. US Geol. Surv. OpenFile Rep., 90-687, 69 pp.

Clague, J.J., Harper, J.R., Hebda, R.J. and Howes, D.E. (1982) Late Quaternary sea levels and crustal movements, coastal British Columbia. Can. J. Earth Sci., 19, 597-618.

Colman, S.M., Karabanov, E.B. and Nelson, C.H., III (2003) Quaternary sedimentation and subsidence history of Lake Baikal, Siberia, based on seismic stratigraphy and coring. J. Sed. Res., 73, 941-956.

Coulter, H.W. and Migliaccio, R.R. (1966) Effects of the earthquake of March 27, 1964 at Valdez, Alaska. US Geol. Surv. Prof. Pap., 542-C, 36.

Crandell, D.R. (1971) Postglacial lahars from Mount Rainier volcano, Washington. US Geol. Surv. Prof. Pap., 677, 75.

Davis, J.L. and Annan, A.P. (1989) Ground-penetrating radar for high-resolution mapping of soil and rock stratigraphy. Geophys. Prospect., 37, 531-551.

Dragovich, J.D., Pringle, P.T. and Walsh, T.W. (1994) Extent and geometry of the mid-Holocene Osceola mudflow in the Puget lowland - implications for Holocene sedimentation and paleography. Wash. Geol., 22, 3-26.

Gardner, J., van den Ameele, E., Gelfenbaum, G., Barnhardt, W., Lee, H. and Palmer, S. (2001) Mapping southern Puget Sound Delta fronts after the 2001 Nisqually earthquake. US Geol. Surv. Open-File Rep., 01-266, [http://geopubs.wr.usgs.gov/ open-file/of01-266/html/article.htm].

Hayes, M.O. (1979) Barrier island morphology as a function of tidal and wave regime. In: Barrier Islands (Ed. S.P. Leatherman), pp. 3-22. Academic Press, New York.

van Heteren, S., Fitzgerald, D.M., Barber, D.C., Kelley, J.T. and Belknap, D.F. (1996) Volumetric analysis of a New England barrier system using ground-penetrating-radar and coring techniques. J. Geol., 104, 471-483.

Huggenberger, P. (1993) Radar facies: recognition of facies patterns and heterogeneities within Pleistocene Rhine gravels, NE Switzerland. In: Braided Rivers (Eds J.L. Best and C.S. Bristow), Geol. Soc. Spec. Publ. (London), 75, 163176.

Inman, D.L. and Nordstrom, C.E. (1971) On the tectonic and morphologic classification of coasts. J. Geol., 79, 1-21. 
James, T.S., Clague, J.J., Wang, K. and Hutchinson, I. (2000) Postglacial rebound at the northern Cascadia subduction zone. Quatern. Sci. Rev., 19, 1527-1541.

Jervey, M.T. (1988) Quantitative geological modeling of siliciclastic rock sequences and their seismic expression. In: Sea-level Changes; an Integrated Approach (Eds C.K. Wilgus, B.S. Hastings, C.A. Ross, H. Posamentier, J. Van Wagoner and C.G. Kendall), SEPM Spec. Publ., 42, 47-69.

Kuenzi, W.D., Horst, O.H. and McGehee, R.V. (1978) Effect of volcanic activity on fluvial-deltaic sedimentation in a modern arc-trench gap, southwestern Guatemala. Geol. Soc. Am. Bull., 90, 827-838.

Meier, M.F., Carpenter, P.J. and Janda, R.J. (1981) Hydrological effects of Mount St. Helens' 1980 eruptions. EOS Trans. Am. Geophys. Union, 62, 625-626.

Mitchum, R.J., Jr, Vail, P.R. and Thompson, S., III (1977) The depositional sequence as a basic unit for stratigraphic analysis. In: Seismic Stratigraphy - Applications to Hydrocarbon Exploration (Ed. C.E. Payton), AAPG Mem., 26, 53-62.

van Overmeeren, R.A. (1998) Radar facies of unconsolidated sediments in The Netherlands: a radar stratigraphy interpretation for hydrogeology. J. Appl. Geophys., 40, 1-18.

Palmer, S.P., Pringle, P.T. and Schulene, J.A. (1991) Analysis of liquefiable soils in Puyallup, Washington. In: Proceedings of Fourth International Conference on Seismic Zonation (Eds R.D. Borcherdt and H.C. Shah), pp. 621-628. Earthquake Engineering Research Institute, Stanford, CA.

Palmer, S.P., Schasse, H.W. and Norman, D.K. (1994) Liquefaction Susceptibility for the Des Moines and Renton 7·5minute Quadrangles, Washington. Washington Division of Geology and Earth Resources, Geologic Map GM-41, scale 1:24000, Olympia, Washington.

Penland, S., Boyd, R. and Suter, J.R. (1988) Transgressive depositional systems of the Mississippi delta plain: a model for barrier shoreline and shelf sand development. J. Sed. Petrol., 58, 932-949.

Pentcheff, D. (2000) Tide and Current Predictor. University of South Carolina, Columbia, SC [http://tbone.biol.sc.edu/ tide].

Pierson, T.C. and Scott, K.M. (1985) Downstream dilution of a lahar: transition from a debris flow to hyperconcentrated streamflow. Water Resour. Res., 21, 1511-1524.

Porter, S.C. and Swanson, T.W. (1998) Radiocarbon age constraints on rates of advance and retreat of the Puget Lobe of the Cordilleran Ice Sheet during the last glaciation. Quatern. Res., 50, 205-213.

Pringle, P.T. and Palmer, S.P. (1992) Liquefiable volcanic sands in Puyallup, Washington, correlate with Holocene pyroclastic flow and lahar deposits in upper reaches of the Puyallup River valley. Geol. Soc. Am. Abs. Prog., 24, 76.

Scott, J.L. (1982) Sediment transport along a delta shoreline. Bull. Assoc. Eng. Geol., 19, 101-116.

Scott, K.M. (1988) Origins, behavior, and sedimentology of lahars and lahar-runout flows in the Toutle-Cowlitz River system. US Geol. Surv. Prof. Pap., 1447B, 33.

Scott, K.M., Vallance, J.W. and Pringle, P.T. (1995) Sedimentology, behavior and hazards of debris flows at Mount Rainier, Washington. US Geol. Surv. Prof. Pap., 1547, 56.

Sherrod, B.L. (2001) Evidence for earthquake-induced subsidence about $1100 \mathrm{yr}$ ago in coastal marshes of southern
Puget Sound, Washington. Geol. Soc. Am. Bull., 113, 12991311.

Sisson, T.W., Vallance, J.W. and Pringle, P.T. (2001) Progress made in understanding Mount Rainier's hazards. EOS Trans. Am. Geophys. Union, 82, 113, 118-120.

Smith, G.A. (1986) Coarse-grained nonmarine volcaniclastic sediment: Terminology and depositional process. Geol. Soc. Am. Bull., 90, 1-10.

Smith, G.A. and Lowe, D.R. (1991) Lahars: Volcano-hydrologic events and deposition in the debris flow-hyperconcentrated flow continuum. In: Sedimentation in Volcanic Settings (Eds R.V. Fisher and G. A. Smith), SEPM Spec. Publ., 45, 59-70.

Stuiver, M. and Reimer, P. J. (1993) Extended ${ }^{14} \mathrm{C}$ database and revised CALIB radiocarbon calibration program. Radiocarbon, 35, 215-230 [http://depts.washington.edu/ qil/calib/].

Syvitski, J.P.M. and Farrow, G.E. (1983) Structures and processes in bayhead deltas: Knight and Bute Inlet, British Columbia (Klinaklini, Homathko Rivers). Sedimentology, 36, 217-244.

Taylor, G. and Woodyer, K.D. (1978) Bank deposition in suspended-load streams. In: Fluvial Sedimentology (Ed. A.D. Miall), Can. Soc. Petrol. Geol. Mem., 5, 257-275.

Thorson, R.M. (1980) Ice-sheet glaciation of the Puget Lowland, Washington, during the Vashon Stade (late Pleistocene). Quatern. Res., 13, 303-321.

Thorson, R.M. (1989) Glacio-isostatic response of the Puget Sound area, Washington. Geol. Soc. Am. Bull., 101, 11631174 .

U.S. Navy (1953) Puget Sound and Approaches. Hydrographic Office Misc. Chart 15359-8A, 1st edn, scale 1:36,000, contour interval one fathom, six sheets.

University of Washington (1970) The Nisqually Delta. Department of Geological Sciences Report, University of Washington, Seattle, WA, 84 pp.

Vessell, R.K. and Davies, D.K. (1981) Nonmarine sedimentation in an active fore arc basin. In: Recent and Ancient Nonmarine Depositional Environments; Models for Exploration (Eds F.G. Ethridge and R.M. Flores), SEPM Spec. Publ., 31, 31-45.

Walsh, T.J., Wegmann, K.W., Pringle, P.T., Palmer, S.P., Norman, D.K., Polenz, M., Logan, R.L., McKay, D.T., Magsino, S.L. and Schasse, H.W. (2002) Ground failures in the southern Puget Sound lowlands caused by the Nisqually earthquake. Geol. Soc. Am. Abs. Prog., 34, 112.

Williams, H.F.L. and Roberts, M.C. (1989) Holocene sea-level change and delta growth - Fraser River delta, British Columbia. Can. J. Earth Sci., 26, 1657-1666.

Williams, J.R., Pearson, H.E. and Wilson, J.D. (1985) Streamflow statistics and drainage-basin characteristics for the Puget Sound region, Washington. US Geol. Surv. Open-File Rep., 84-144A, 330.

Wright, L.D. and Coleman, J.M. (1974) Mississippi River mouth processes: effluent dynamics and morphologic development. J. Geol., 82, 751-778.

Manuscript received 28 July 2003; revision accepted 31 May 2006 